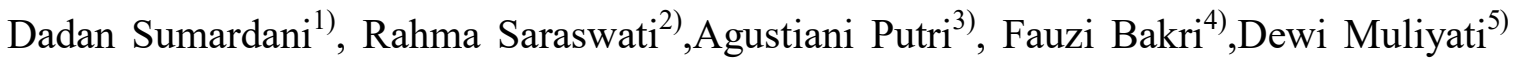
Informatika : Fakultas Sains dan Teknologi

Universitas Labuhanbatu

Vol. 8 No.1 / Januari/2020

2615-1855 (E-ISSN)

2303-2863 (P-ISSN)

\title{
SYSTEM IMPLEMENTATION OF AUGMENTED REALITY APPLICATION IN STUDENT WORKSHEET
}

\author{
Dadan Sumardani ${ }^{1)}$ \\ Pendidikan Fisika, Universitas Negeri Jakarta \\ e-mail: dadansumardani_pfisika15s1@mahasiswa.unj.ac.id \\ Rahma Rosaliana Saraswati ${ }^{2)}$ \\ Pendidikan Matematika, Universitas Negeri Jakarta \\ e-mail: rahma.rosaliana@gmail.com \\ Agustiani Putri ${ }^{3)}$ \\ Pendidikan Matematika, Universitas Negeri Jakarta \\ e-mail: agustianiputri15@gmail.com \\ Fauzi Bakri ${ }^{4}$ \\ Dosen Pendidikan Fisika, Universitas Negeri Jakarta \\ e-mail: fauzi-bakri@unj.ac.id \\ Dewi Muliyati ${ }^{5)}$ \\ Dosen Pendidikan Fisika, Universitas Negeri Jakarta \\ e-mail:dmuliyati@unj.ac.id
}

\begin{abstract}
ABSTRAK
Augmented Realityhadir sebagai teknologi berkembang yang memiliki potensi pedagogis yang besar. Pemanfaatan teknologi ini sangat masif dikembangkan dalam pratikum. Fisika adalah mata pelajaran yang memerlukan praktikum agar siswa memahami esensi fisika.Masalah yang diangkat dalam penulisan penelitian ini adalah bagaimana implementasi sistem augmented reality pada lembar kerja peserta didik. Oleh sebab itu, tujuan diadakannya penelitian ini adalah membuat aplikasiAugmented Reality pada LKPD materi kaidah tangan kanan. Metode pengembangan sistem yang digunakan adalah metode waterfall. Hasil dari pengembangan sistem ini adalah terciptanya sebuah aplikasi Augmented Reality untuk membantu guru dalam memandu siswa dan membantu siswa dalam memahami materi fisika. Dari hasil pengujian black box testing, didapatkan hasil pengujian bahwa persentasi keberhasilan sistem aplikasi sebesar 100\% yang mengindikasikan bahwa aplikasi telah berfungsi dengan baik pada penggunaan di smartphone. Sehingga aplikasi ini sudah dapat digunakan pada pengguna dalam proses pembelajaran.
\end{abstract}

\section{Kata kunci: Augmented Reality,Implementasi Sistem, Worksheet}

\section{ABSTRACT}

Augmented Reality exists as a developing technology that has great pedagogical potential. Utilization of this technology is very massive developed in the practice. Physics 
Dadan Sumardani ${ }^{1)}$, Rahma Saraswati ${ }^{2)}$,Agustiani Putri ${ }^{3)}$, Fauzi Bakri ${ }^{4)}$,Dewi Muliyati ${ }^{5)}$ Informatika : Fakultas Sains dan Teknologi

Universitas Labuhanbatu

Vol. 8 No.1 / Januari/2020

2615-1855 (E-ISSN)

2303-2863 (P-ISSN)

is a subject that requires practicum so students understand the essence of physics. The problem raised in writing this research is how the implementation of the augmented reality system on the student worksheets. Therefore, the purpose of this research is to make Augmented Reality application on LKPD on right hand rules. The system development method used is the waterfall method. The result of the development of this system is the creation of an Augmented Reality application to assist teachers in guiding students and helping students understand physics material. From the results of black box testing, the test results show that the percentage of application system success is $100 \%$, which indicates that the application is functioning properly on smartphone usage. So this application can already be used by users in the learning process.

\section{Keywords: Augmented Reality, System Implementation, Worksheet.}

\section{PENDAHULUAN}

Tingkat pendidikan sains di Indonesia sampai saat ini masih dalam tahap pengembangan. Menurut the learning curve peringkat mutu pendidikan Indonesia adalah peringkat 40 dari 40 negara (Hidayat, 2018). Hal ini berarti banyak yang harus dibenahi dan diperhatikan dalam dunia pendidikan di Indonesia, salah satunya adalah pada sistem penyampaian materi pelajaran beserta proses dan hasil dari pendidikan itu sendiri. Kesuksesan pendidikan tidak bisa terlepas dari hal tersebut, baik pada tingkat pendidikan dasar sampai perguruan tinggi. .

Kurangnya pemahaman peserta didik terhadap sains tergambar pula berdasarkan survey Programme of International Student Assessment (PISA) yang menggambarkan posisi prestasi sains Indonesia 2012 yang berada di posisi 64 dari total 65 negara yang di survey dan pada tahun 2012 sebesar 64 dari 65 negara yang di survey (OECD, 2015). Namun, meskipun hasil peningkatan tersebut cukup signifikan, tingkat prestasi sains masih jauh dibandingkan dengan negara-negara yang lain. Indonesia masih berada di peringkat kelas bawah dan kalah jauh dengan Singapura.

Fisika adalah salah satu mata pelajaran yang memerlukan banyak media untuk menyampaikan maupun menjelaskan materi. Dalam pelajaran fisika, tidak hanya belajar sebatas konsep maupun rumus saja, melainkan banyak kejadian yang tidak bisa dipahami dengan hanya membaca apalagi mendengar lewat ceramah. Dalam rangka menyampaikan materi fisika yang abstrak, dibutuhkan praktikum yang terbilang efektif membuat peserta didik memahami relevansi fisika dengan kehidupan nyata(Hidayati, 2012; Hayat,\& Anggraeni, 2011; Pyatt, 2012). Namun, dalam survey yang dilakukan peneliti di SMA Negeri 5 Jakarta tanggal 8 November 2018, guru Fisika menyatakan bahwa proses praktikum masih banyak kendala dan menyebabkan tujuan praktikum tidak tercapai. Banyak hak yang membuat tidak maksimalnya praktikum, diantaranya adalah jumlah siswa yang terlalu banyak, tidak adanya lembar kerja siswa yang interaktif, dan keterbatasan media.Praktium dapat dilakukan baik dengan menggunakan simulasi penyederhanaan kondisi nyata kedalam konsep sederhana, seperti simulasi refraksi cahaya (Srisawasdi, 2014) dan simulasi Gaya Gerak Listrik (Bakri, 2019).Praktikum menggunakan teknologi augmented reality dapat memaksimalkan aktivitas minds-on peserta didik dalam 
Dadan Sumardani ${ }^{1)}$, Rahma Saraswati ${ }^{2)}$,Agustiani Putri ${ }^{3)}$, Fauzi Bakri ${ }^{4)}$,Dewi Muliyati ${ }^{5)}$ Informatika : Fakultas Sains dan Teknologi

Universitas Labuhanbatu

Vol. 8 No.1 / Januari/2020

2615-1855 (E-ISSN)

2303-2863 (P-ISSN)

praktikum (Taşlıdere, 2015) serta lebih interatif bagi peserta didik (Sumardani, 2019).

Penelitian Fauzi Bakri (2019) telah mengembangkan lembar kerja peserta didik (LKPD)untuk melatih kemampuan berpikir tingkat tinggi SMA dan menghasilkan kesimpulan bahwa LKPDdilengkapi video melalui augmented realitydapat digunakan dalam pembelajaran untuk melatih kemampuan berpikir tingkat tinggi siswa SMA kelas XII. Namun sayangnya, dalam konten penelitian tersebut hanya berupa video tanpa stimulus animasi.

Selain masalah pratikum, LKPD hanya berisi tulisan dan beberapa gambar 2D yang membuat siswa merasa bosan dan kurang berimajinatif. Penggunaan gambar diam yang telah tersedia dalam buku teks membuat siswa cenderung pasif dan kurang interaktif karena media gambar 2D tidak mampu memberikan respon timbal balik, kurang terlihat nyata dan kurang menarik bagi siswa(Yusniawati, 2011). Beberapa penelitian yang memanfaatkan teknologi untuk membantu efektifitas proses pembelajaran menggunakan teknologi augmented realitybanyak dilakukan dalam mengembangkan animasi agar lebih interaktif. Animasi augmented reality tersebut seperti pengembangan pada penerapan gerak lorentz (Bakri, 2019).

Mobile Augmented Reality adalah salah satu teknologi yang berkembang yang memiliki potensi pedagogis yang besar. Dengan kemampuan menggabungkan dunia virtual dan nyata bersama-sama telah melahirkan kemungkinan baru dalam meningkatkan kualitas kegiatan belajar mengajar. Keefektifan AR dapat lebih diperluas ketika digabungkan dengan jenis teknologi lain seperti perangkat seluler (Nincarean, 2013).

Berdasarkan latar belakang yang dikemukakan di atas, maka penulis tertarik untuk melakukan penelitian dalam implementasi sistem Augmented Realitypada Lembar Kerja Peserta Didik.

\section{METODE PENELITIAN}

Penelitian ini merupakan penelitian pengembangan sistem perangkat lunak, sehingga dalam pembuatannya menggunakan metode pengembangan sistem yang sesuai dengan kaidah rekayasa perangkat lunak. Penelitian ini menggunakan metode System Life Cycle Development (SLDC) tipe waterfall atau selanjutnya disebut metode waterfall. Metode ini dipilih karena tahapannya yang sistematis dan mudah untuk diaplikasikan. Tahapan pengembangan system dimulai dengan spesifikasi kebutuhan pengguna lalu berlanjut melalui tahapantahapan perencanaan (planning), permodelan (modeling), konstruksi (construction), serta penyerahan system ke para pengguna (deployment), yang diakhiri dengan dukungan pada perangkat lunak lengkap yang dihasilkan (Pressman, 2012). Namun dalam penelitian ini belum meliputi tahap deployment karena keterbatasan peneliti dalam menyebarkan aplikasi kepada pengguna secara luas.

\section{HASIL DAN PEMBAHASAN}

Hasil penelitian yang dilakukan menghasilkan aplikasi yang secara sistem telah berjalan dengan baik. Hasil dari pengembangan aplikasi secara sistematis dijabarkan menggunakan metode waterfall.

\subsection{Perencanaan}

Tahap pertama yang dilakukan untuk pengembangan sistem adalah analisis masalah. Masalah dikumpulkan dengan menggunakan wawancara tidak terstruktur kepada narasumber. Narasumber yang dimaksud adalah Guru Fisika SMA Negeri 5 Jakarta yaitu Bapak Dwi Priandoyo pada 
Dadan Sumardani ${ }^{1)}$, Rahma Saraswati ${ }^{2)}$,Agustiani Putri ${ }^{3)}$, Fauzi Bakri ${ }^{4)}$,Dewi Muliyati ${ }^{5)}$ Informatika : Fakultas Sains dan Teknologi

Universitas Labuhanbatu

Vol. 8 No.1 / Januari/2020

2615-1855 (E-ISSN)

2303-2863 (P-ISSN)

tangal 8 Novermber 2018. Selain menggunakan wawancara, peneliti juga mengumpulkan beberapa artikel hasil penelitian untuk mengidentifikasi masalah-masalah di dalam pelaksanaan praktikum. Hasil yang didapatkan dari analisis masalah yaitu kurangnya media penunjang, ketersediaan Lembar Kerja Peserta Didik yang kurang inteeraktif, tujuan Pembelajaran yang tidak tersampaikan, dan sulitnya mengontrol praktikum dengan 36 peserta didik.

\subsection{Pemodelan}

Dari masalah yang sudah diidentifikasi, kemudian desain dilakukan untuk membantu pengembangan sistem. Masalah yang muncul akan dibuat menjadi fitur-fitur yang tersedia dalam aplikasi ini. Desain yang dilakukan menggunakan use case diagram,entity relational diagram dan mockup.

\subsubsection{Use Case Diagram}

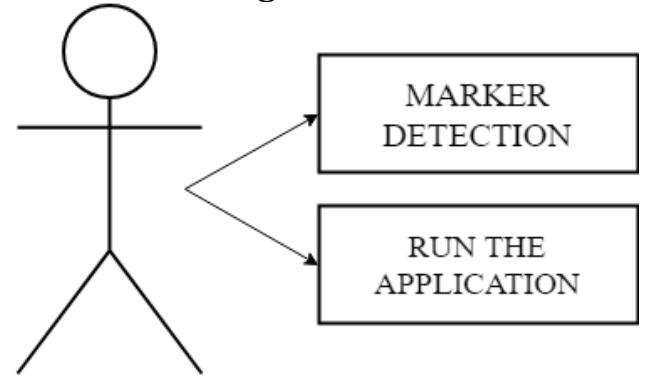

USER

Gambar 1.Use case diagram

Use Case Diagram (Gambar 1)menunjukkan bagaimana pengguna aplikasi (user) berinteraksi dengan aplikasi yang dikembangkan oleh peneliti. Dalam use case tersebut dijelaskan bahwa aktor yang terlibat yaitu Peserta Didik dan guru yang berperan sebagai pengguna aplikasi atau user. Peserta didik dalam melakukan praktikum akan diberikan lembar kerja siswa yang sudah dilengkapi dengan augmented reality sebagai pemandunya berpraktikum.

\subsubsection{Flowchart Aplikasi}

Flowchart aplikasi dibuat untuk menggambarkan logika yang digunakan dalam menyusun sistem aplikasi ini.Flowchart yang digunakan ditampilkan pada Gambar 2.

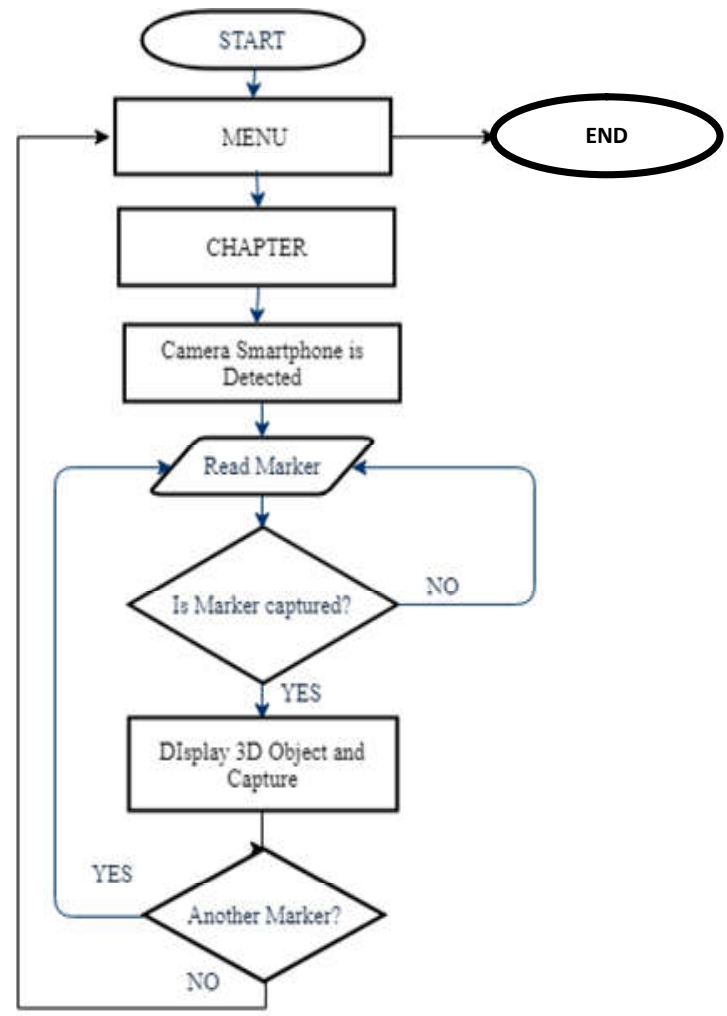

Gambar 2.Flowchartaplikasi

\subsubsection{Mockup}

Mockup merupakan desain awal tampilan yang akan dibuat. Mockup mendefinisikan bagaimana tampilan yang akan dimuat di dalam aplikasi. Berikut beberapa mockup aplikasi Augmented Reality. 
Dadan Sumardani ${ }^{1)}$, Rahma Saraswati ${ }^{2)}$,Agustiani Putri ${ }^{3)}$, Fauzi Bakri ${ }^{4)}$,Dewi Muliyati ${ }^{5)}$ Informatika : Fakultas Sains dan Teknologi

Universitas Labuhanbatu

Vol. 8 No.1 / Januari/2020

2615-1855 (E-ISSN)

2303-2863 (P-ISSN)

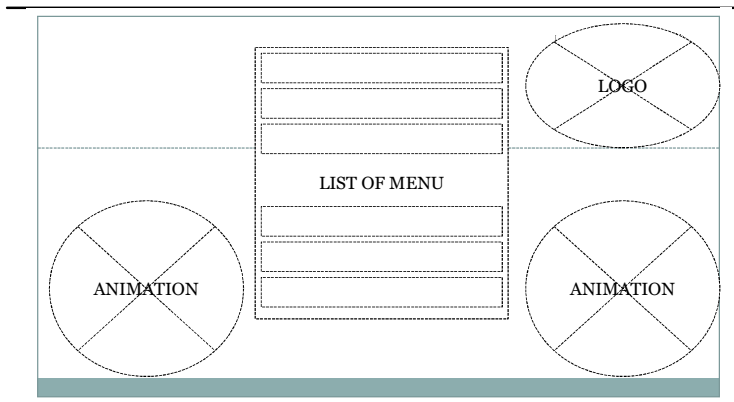

Gambar 3.Mockuptampilan utama

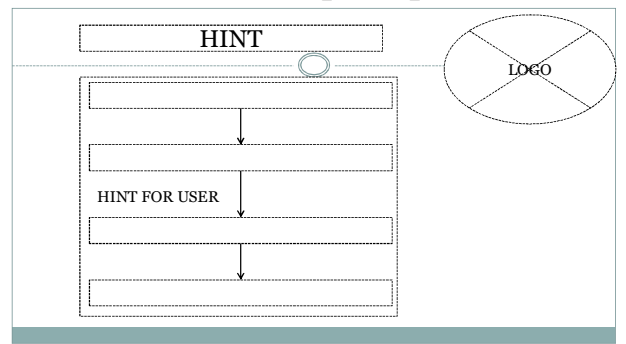

Gambar 4.Mockuptampilan petunjuk

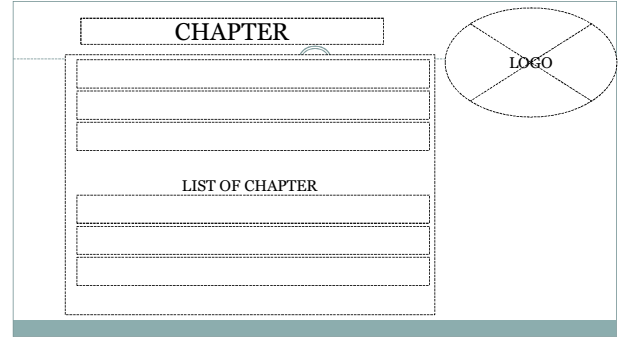

Gambar 5.Mockuptampilan materi

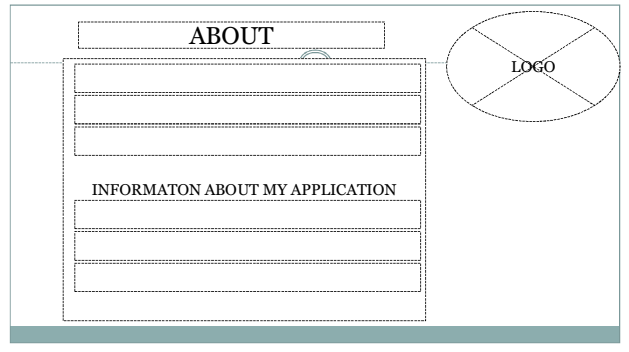

Gambar 6Mockuptampilan tentang

Gambar 3-6 merupakan rancangan interface yang dikembangkan pada penelitian. Selanjutnya akan dilakukan desain menggunakan aplikasi pengolola grafis.

\subsection{Konstruksi}

Dalam pembuatan aplikasi ini, peneliti menggunakan aplikasi Unity 5.2.6 32-bit. Unity merupakan aplikasi open source yang biasa digunakan untuk membuat game 3D maupun 2D. Peneliti juga menggunakan aplikasi Blender untuk membuat objek dan animasi bergerak di dalam unity. Untuk kebutuhan marker augmented reality peneliti menggunakan juga vendor vuforia untuk mensupport aplikasi ini dengan baik.

\subsubsection{Hasil implementasi antarmuka}

Programming dibutuhkan untuk pembuatan aplikasi menggunakan Microsof Visual Basic berbahasa C\#. Pembuatan antarmuka dilakukan menggunakan aplikasi desain grafis yaitu Microsoft Office PowerPoint 2007, Inkscape dan Unity 5.6.2.

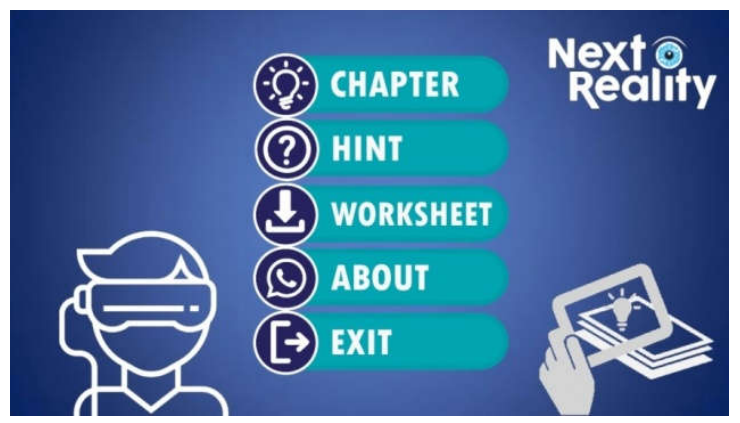

Gambar 7. Halaman Utama

Pada Gambar 7 halaman yang muncul ketika pertamakali orang menggunakan aplikasi ini. Di sini akan muncul list materi, sound opening aplikasi, dan logo aplikasi augmented reality. Pada halaman utama ini terdapat pilihan worksheet yang jikaditekan akan menuju ke link untuk mengunduh lembar kerja peserta didik. 
Dadan Sumardani ${ }^{1)}$, Rahma Saraswati ${ }^{2)}$,Agustiani Putri ${ }^{3)}$, Fauzi Bakri ${ }^{4)}$,Dewi Muliyati ${ }^{5)}$ Informatika : Fakultas Sains dan Teknologi

Universitas Labuhanbatu

Vol. 8 No.1 / Januari/2020

2615-1855 (E-ISSN)

2303-2863 (P-ISSN)

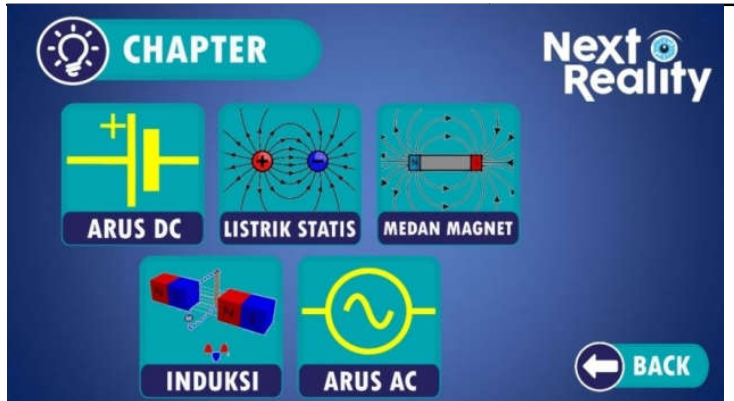

Gambar8. Halaman Pilihan Materi

Halaman Gambar 8ditampilkan materi terkait yang ada pada aplikasi. Materi yang tersedia adalah materi dalam kaidah tangan kanan.

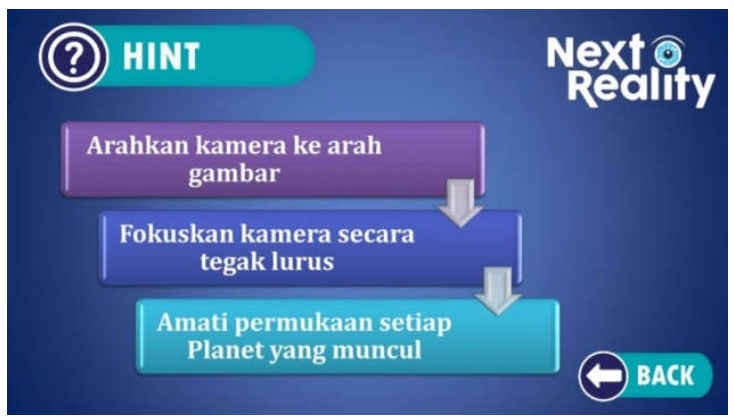

Gambar 9. Halaman Petunjuk

Halaman Gambar 9 merupakan halaman petunjuk untuk orang yang bingung cara menggunakan aplikasi ini. Dihalaman ini akan diterangkan cara menggunakan aplikasi ini dengan ringkas.

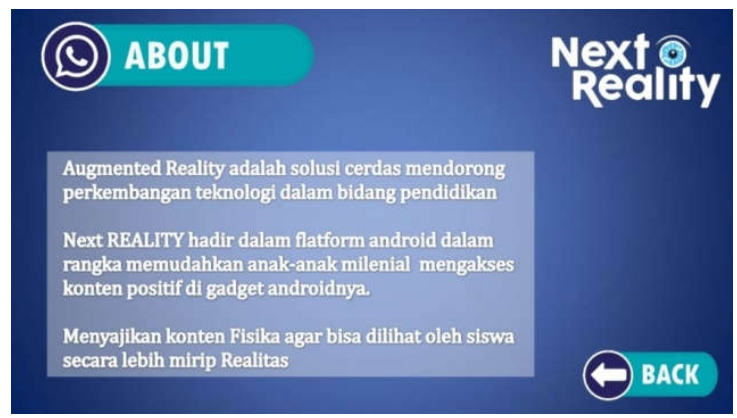

Gambar 10. Halaman Tentang
Halaman Gambar 10 merupakan halaman identitas dari aplikasi ini. Halaman ini memuat deskripsi singkat mengapa hadir aplikasi ini dan perkenalan singkat tentang augmented reality.

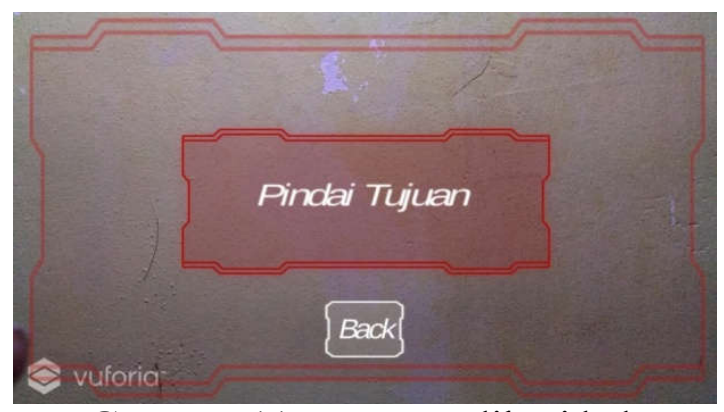

Gambar 11.Camera aplikasi belum menemukan Marker

Halaman Gambar 11 merupakan halaman saat aplikasi belum menemukan marker. Saat aplikasi belum menemukan marker maka layout akan terlihat merah dan bertuliskan Pindai. Setelah di pindai maka akan muncul objek yang sesuai marker.

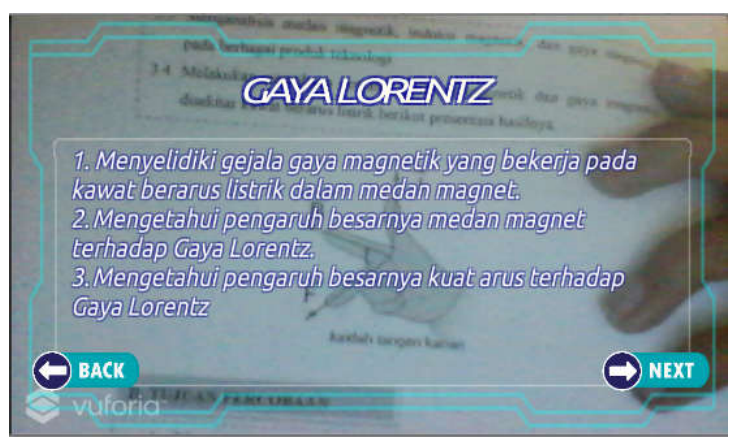

Gambar 12.Camera memindai MarkerTujuan Belajar

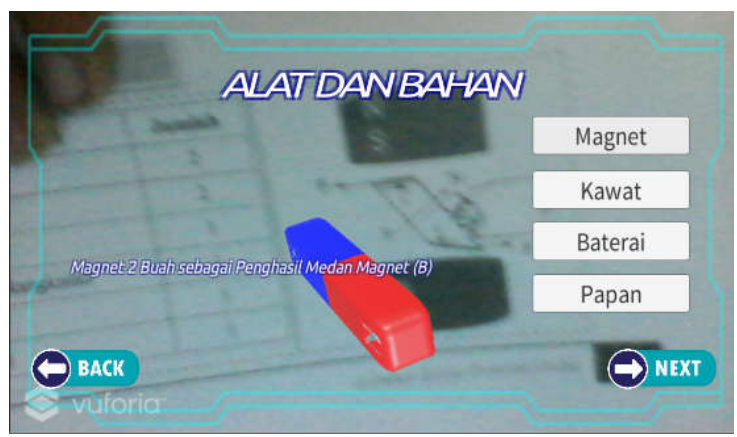


Dadan Sumardani ${ }^{1)}$, Rahma Saraswati ${ }^{2)}$,Agustiani Putri ${ }^{3)}$, Fauzi Bakri ${ }^{4)}$,Dewi Muliyati ${ }^{5)}$ Informatika : Fakultas Sains dan Teknologi

Universitas Labuhanbatu

Vol. 8 No.1 / Januari/2020

2615-1855 (E-ISSN)

2303-2863 (P-ISSN)

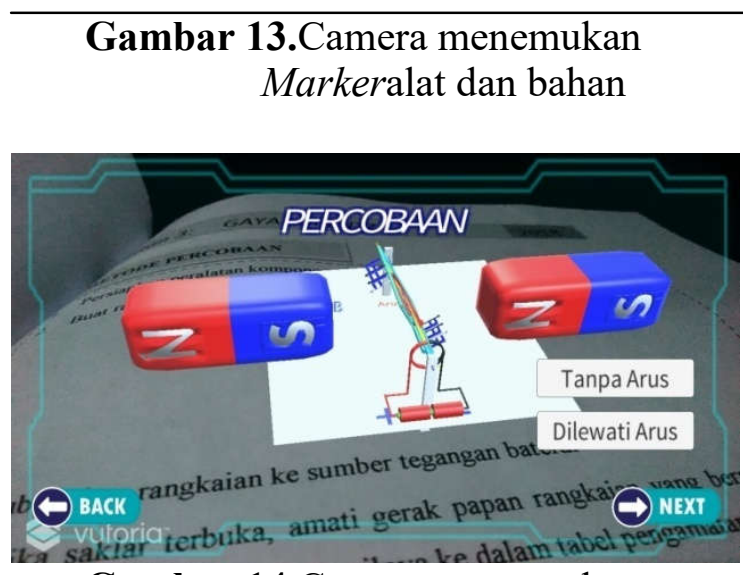

Gambar 14.Camera menemukan Markerpercobaan

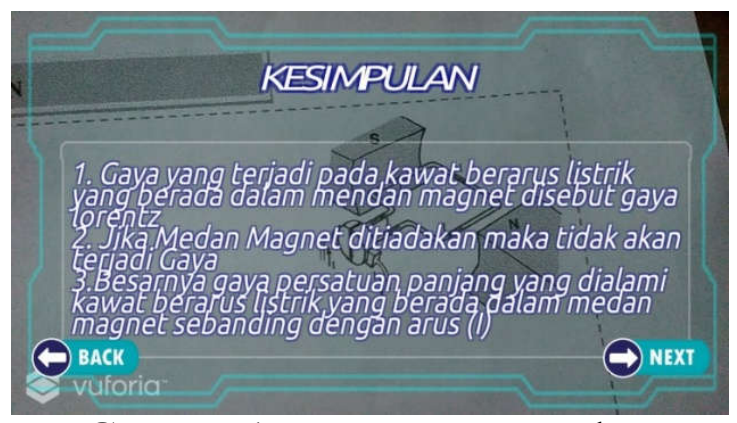

Gambar 15. Kamera menemukan Markerkesimpulan

Marker pada Gambar 12-15 merupakan objek yang muncul saat marker dipindai menggunakan aplikasi. Pengguna akan diajak memilih komponen yang ingin dimunculkan pada aplikasi secara interaktif.

Lembar kerja peserta didik yang dikembangkan terdiri dari beberapa komponen dan terdiri dari beberapa marker penting. Marker tersebut di cetak pada LKPD dan dapat dipindai. Tampilan LKPD terlihat pada Gambar 16.

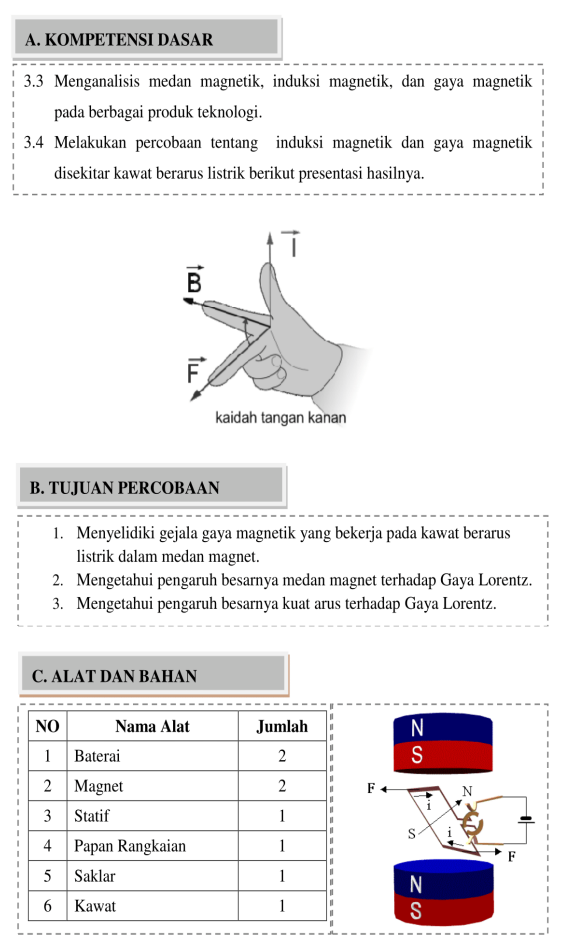

Gambar 16.1 Tampilan LKPD 2.3.2Hasil Pengujian

Pengujian pada aplikasi yang telah dikembangkan selanjutnya dilakukan menggunakan blackbox testing. Adapun instrument ditampilkan dan hasil yang diharapkan ditampilkan pada Tabel 1 berikut.

Tabel 1. Instrumen Penilaian

\begin{tabular}{l|c}
\hline \multicolumn{1}{c}{ Skenario Pengujian } & Skala \\
\hline Install aplikasi di smartphone & \\
Membuka aplikasi & \\
Klik menu petunjuk & $1 / 0$ \\
Klik menu chapter & \\
Klik menu about & (Success/ \\
Klik menu unduh worksheet & Failed) \\
Klik menu back & \\
Memindai marker pada LKPD & \\
\hline
\end{tabular}

Selanjutnya dilakukan uji coba pada aplikasi. Hasil pengujian ditampilkan pada Tabel 2 sebagai berikut. 


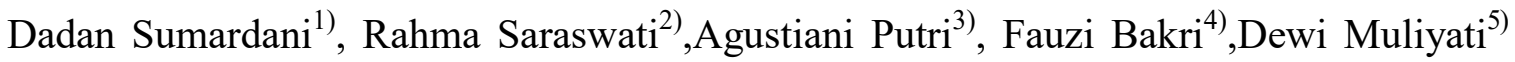
Informatika : Fakultas Sains dan Teknologi

Universitas Labuhanbatu

Vol. 8 No.1 / Januari/2020

2615-1855 (E-ISSN)

2303-2863 (P-ISSN)

Tabel 2.Hasil Pengujian Black Box Testing

\begin{tabular}{ll}
\hline \multicolumn{1}{c}{ Hasilyangdiharapkan } & \multicolumn{1}{c}{ Hasil } \\
\hline Aplikasi terinstall & Success \\
Aplikasi terbuka & Success \\
Menampilkan page petunjuk & Success \\
Menampilkan pagechapter & Success \\
Menampilkan pageabout & Success \\
Menampilkan pageunduh & Success \\
Tampil pagesebelumnya & Success \\
Objek AR muncul & Success \\
\hline
\end{tabular}

Hasil pengujian menunjukkan bahwa dari beberapa item ujicoba. Didapatkan hasil sebagai berikut ditampilkan pada Tabel 3 berikut.

Tabel 3.Persentase Pengujian Black Box Testing

\begin{tabular}{lccc}
\hline \multicolumn{1}{c}{ Hasil } & Ordinal & Total & Persentase \\
\hline Success & 1 & 8 & $100 \%$ \\
Failed & 0 & 0 & $0 \%$ \\
\hline
\end{tabular}

Hasil pengujian didapatkan hasil bahwa persentasi keberhasilan fungsi dalam sistem aplikasi yang dikembangkan adalah $100 \%$ sudah berfungsi dengan baik. Keberhasilan sistem itu ditinjau dari 8 item testyang berhasil lolos, diantaranya proses instalasi yang berjalan lancar dan penampil objek augmented reaityyang muncul saat marker dipindai.

\section{KESIMPULAN DAN SARAN}

Hasil dari penelitian ini adalah terciptanya sebuah aplikasi sistem augmented realitypada lembar kerja peserta didik untuk pelaksanaan pembelajaran.Setelah dilakukan pengujian dengan metode black box testing, didapatkan hasil pengujian bahwa persentasi keberhasilan dalam sistem aplikasi ini adalah $100 \%$ sudah berfungsi dengan baik pada penggunaan di smartphone. Sehingga aplikasi ini sudah dapat digunakan pada penggunadalam proses pembelajaran.

\section{UCAPAN TERIMA KASIH}

Terimakasih kepada Kelompok Peneliti Muda dan Laboratorium Media Digital Universitas Negeri Jakarta. Terimakasih kepada Bapak Fauzi Bakri, S.Pd., M.Si. dan Ibu Dewi Muliyati, S.Pd., M.Si., M.Sc. atas bimbingannya dalam penulisan artikel ilmiah.

\section{REFERENCES}

Bakri, F., Sumardani, D., \& Muliyati, D. 2019). Integrating Augmented Reality Into Worksheets: Unveil Learning To Support Higher-Order Thinking Skills. AIP Conference Proceedings 2169, 020012.

Bakri, F., Sumardani, D \& Muliyati, D. (2019). The Augmented Reality Application for Simulating Electromotive Force Concept. Journal of Physics: Conference Series, 1402(6).

Bakri, F., Sumardani, D \& Muliyati, D. (2019). The 3D Simulation of Lorentz Force Based on Augmented Reality Technology. Journal of Physics: Conference Series, 1402(6).

Hayat, M. S., \& Anggraeni, S. (2011). Sikap Ilmiah Siswa Praktikum Based Learning On Invertebrate Concept To Students' Scientific Attitude Development. Jurnal Penelitian, 02.

Hidayat, F. (2018). Anies Baswedan: Mutu pendidikan Indonesia gawat darurat. Retrieved from https://www.merdeka.com/peristiwa/a 


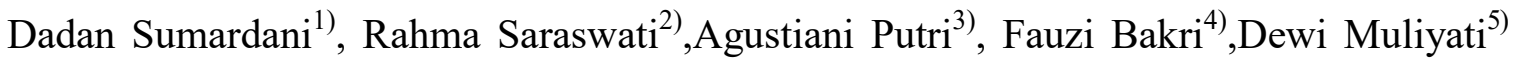
Informatika : Fakultas Sains dan Teknologi

Universitas Labuhanbatu

Vol. 8 No.1 / Januari/2020

2615-1855 (E-ISSN)

2303-2863 (P-ISSN)

nies-baswedan-mutu-pendidikanindonesia-gawat-darurat.html, on 3 July 2019.

Hidayati, N. (2012).Penerapan Metode Praktikum dalam Pembelajaran Kimia untuk Meningkatkan Keterampilan Berpikir Tingkat Tinggi Siswa pada Materi Pokok Kesetimbangan Kimia Kelas XI SMK Diponegoro Banyuputih Batang. Skripsi. IAIN Walisongo.

OECD. (2015). Programme for International Student Assessment 2015: Results in Focus. Retrieved from www.oecd.org/pis. January 1, 2019.

Nincarean, D. et al. (2013). Mobile Augmented Reality: The Potential for Education. Procedia - Social and Behavioral Sciences, 103. 657-664.

Pressman, Roger S., P. D. (2012). Rekayasa Perangkat Lunak (Pendekatan Praktisi) Edisi 7. Yogyakarta: Andi Offset.

Pyatt, K., \& Sims, R. (2012). Virtual and Physical Experimentation in InquiryBased Science Labs. J Sci Educ Tech.21, 133-147.

Ramos, J. (2013) 'Higher Order Thinking Skills and Academic Performance in Physics of College Students: A Regression Analysis.', International Journal of Innovative Interdisciplinary Research, (4), pp. 48-60.

Srisawasdi, N., \& Kroothkeaw, S. (2014). Supporting Students' Conceptual Development of Light Refraction by Simulation-based Open Inquiry with Dual-situated Learning Model. $J$. Comput. Educ., 1(1), 49-79.
Sumardani, D., Midaraeni, I., Sumardani, N. I. (2019). Virtual Reality Sebagai Media Pembelajaran Relativitas Khusus Berbasis Google Cardboard pada Smartphone Android. Prosiding Seminar Nasional Pendidikan KALUNI, 2, 309-321.

Taşlıdere, E. (2015). A Study Investigating the Effect of Treatment Developed by Integrating the 5E and Simulation on Pre-service Science Teachers' Achievement in Photoelectric Effect. Eurasia Journal of Mathematics, Science \& Technology Education, 1-16.

Yusniawati, I. (2011). Peningkatan Hasil Belajar IPA Materi Tata Surya dengan Menggunakan Media Interaktif Animasi 3 Dimensi pada Siswa Kelas VI SD Negeri 2 Karanganyar. Skripsi. Universitas Muhammadiyah Surakarta. 